V.H. Ravlyuk ${ }^{1}$, orcid.org/0000-0003-4818-9482, S.V.Mykhalkiv ${ }^{1}$, orcid.org/0000-0002-0425-6295, A.V. Rybin ${ }^{1}$ orcid.org/0000-0003-4430-8018, Ya. V. Derevianchuk ${ }^{1}$, orcid.org/0000-0002-4932-2751, O.A. Plakhtii ${ }^{2}$, orcid.org/0000-0002-1535-8991
1 - Ukrainian State University of Railway Transport, Kharkiv, Ukraine, e-mail: svm_m@ukr.net

2 - Ltd "VO OVEN", Kharkiv, Ukraine

\title{
FORECASTING OF WEAR OF PADS OF MODERNIZED BRAKE SYSTEM DEVICES OF BOGIES OF FREIGHT CARS USING ARIMA MODELS
}

Purpose. The purpose is to create discrete stochastic ARIMA models for forecasting the remaining life of pads of modernized brake rigging (BR) devices of bogies of industrial railway cars.

Methodology. Accounting of statistical data on the wear of pads of typical and modernized BR devices obtained in the relevant studies. On the basis of analytical designs of BR, changes in the junction of the vertical lever with the spacer are proposed. Akaike and Bayesian information criteria are used for selecting the optimal integrated autoregression and moving average model within the Box-Jenkins methodology for forecasting the remaining mileage of pads.

Findings. The ARIMA model was identified, evaluated, and checked for adequacy according to the Akaike and Bayesian information criteria. It is established that abnormal wear of the top of the pads of typical BR devices due to a number of design and operational reasons occurs when the mileage is about 3.5 times less than the forecasted life before the abnormal wear of the top of the pads of modernized BR devices. The forecasted remaining life of the top of the pad of the modernized BR is 3.3 thousand km shorter than that for the bottom of the same pad.

Originality. For the first time, the remaining life of the pads of the modernized BR devices of industrial freight cars was forecasted using discrete stochastic ARIMA models, which require only the availability of discrete values that are recorded during the relevant experimental measurements.

Practical value. The results of the study were verified on experimental rolling stock with modernized devices in the brake systems of bogies. They can be used in the design, upgrade and operation of the brake systems of both the rolling stock which is currently in operation and the new generation of bogies of freight cars.

Keywords: ARIMA model, freight car, wear, forecasting, brake pad, brake rigging

Introduction. In recent years, the technical condition of braking equipment of the rolling stock has been significantly deteriorating, which primarily affects the safety of train traffic in the railway and industrial transport.

As a result of extensive operational surveys on the brake systems of bogies of freight cars of both in the inventory rolling stock of Ukrzaliznytsia JSC and of industrial enterprises, it was revealed that most devices for uniform retraction of pads are in poor condition. One of the reasons is the imperfect design of the bogie brake rigging, which has not been modernized for many decades. After a short time of operation, in a significant number of the devices, the lock with the caliper fails because of the tension, which causes the disabled state and occurrence of tapered dual wear of brake pads, and the other main reason is a design flaw of the triangle.

A typical triangle used in freight car bogies is known to have a balanced design relative to its suspension [1]. But after BR parts are joined to the triangle strut, the condition of balance of the triangle is disturbed. Under the influence of the force created by the weight of the attached parts, it bends as far as it can go, and consequently causes squeezing of the upper ends of the brake pads to the rotor surface of the wheels. Thus, there occurs intense friction of the top of the pads on the rolling surface of the wheels during movement without braking. As a result, local wear increases intensively on the upper parts of the working area of the pads, which leads to their tapered dual wear.

Therefore, the key to successful solving of this problem in the maintenance and repair (MR) of cars is, first, the upgrade of the typical BR, and second, the creation of grounds for their

(C) Ravlyuk V.H., Mykhalkiv S. V., Rybin A. V., Derevianchuk Ya. V., Plakhtii O.A., 2020 use for the entire warranty period of operation of freight cars between overhauls by forecasting the remaining life of the pads in the brake systems of the modernized bogie devices.

Literature review. The problem of tapered dual wear of brake pads, which is associated with the design features of the BR of the bogie, has been known for a long time. It is associated with a decrease in the braking performance of rolling stock due to a decrease in the contact area of the tribotechnical pairs, with the consequent increase in forced repairs, energy costs for train traction and a decrease in the overall economic performance of freight transport [2]. The study on the causes and consequences of this phenomenon is presented in [3], where attention is focused on the fact that the excessive number of elements and unnecessary connections in the BR of the bogie (mod. 18-100) prevents self-restoration of the friction surfaces of the brake pads relative to the rolling planes of the wheels of M 1180.000 uniform retraction devices [4]. After a short period of operation, these devices cannot provide reliable operation of the brakes any more since the dynamic loads acting on their elements cause multiple failures in the operating conditions. In foreign studies $[5,6]$, the performance of rolling stock brake systems is determined by bench tests of wear and temperature indicators, and some focus on the advantages of using cast-iron brake pads [7].

In [1], the method is considered for determining the geometric parameters of the useful contact area of the pads after the upper harmful wear has been formed, depending on the clearance between the wheel and the brake pad, using the coordinate and graphical methods, provided that the devices for uniform retraction of the pads from the wheels are fault-free.

Deterministic methods of exponential smoothing, trend analysis, and stochastic methods are widely used in forecasting. The regression model implements a given form to describe 
the relationship between dependent and independent variables of a time series, which does not always allow considering this model adequate for forecasting the corresponding values. The regression model also has a standard assumption of statistical independence of the error value, although real time series depend mostly on or have autocorrelations between their components. In contrast, modern machine learning methods do not need to make assumptions about the definition of a dependency in the model and automatically determine this dependency during the data learning process $[8-10]$. Neural networks are more intended to process time series with a complex and nonlinear structure. Another approach to time series modeling is the use of the Box-Jenkins methodology or the autoregressive integrated moving average (ARIMA) model [11], which uses input variables, so that the researcher does not have to choose significant variables or the form of dependence between them and is used in a number of applications $[9,12-$ 14]. Although in [8] the ARIMA model demonstrated a higher mean-square error compared to the generalized regression neural network (GRNN) in forecasting coal coke prices, this did not prevent it from making a more accurate forecast with a lower average absolute error and absolute percentage error, and in forecasting changes in wind speed, the ARIMA model had almost half the average absolute percentage error than the back propagation neural network (BPNN) [9]. The ARIMA model also had a lower average absolute percentage error than the nonparametric Gaussian process (GP) model in forecasting electrical energy consumption [14].

Because of the lack of clear or empirical rules for choosing the optimal model for forecasting the remaining life of rolling stock equipment, it is advisable to choose the model that has the least errors based on the results of modeling.

Unsolved aspects of the problem. Based on previous observations made during the operation of freight cars, it was found that the formation and development of tapered dual wear of pads affects the design and condition of the brake system of car bogies. When the mileage of a freight car is about 80 thousand $\mathrm{km}$, an abnormally worn pad should be replaced (its estimated life is 160 thousand $\mathrm{km}$ ), although on average $39 \%$ of its operating weight remains, which means extra operating cost, that can be avoided by upgrading the BR of freight cars that are operated in the railways and industrial transport. This will increase the periods between repairs and mileage on main tracks with reference to prediction of the life of brake pads.

In the studies $[15,16]$ dedicated to the design changes of the $\mathrm{BR}$, there are unresolved problems of tapered dual wear of the pads due to the fact that their developers proposed to create various auxiliary devices to counteract forces that tilt the pads to the wheel only on the basis of kinetostatic analysis of the BR mechanism [17]. However, as practice shows, this approach is associated with the extra complexity of the BR design, extra cost and labour intensity of manufacturing and repair. Therefore, the analyzed studies suggest that the existing problems of tapered dual wear of brake pads, which are used in the brake systems of modern freight cars, have not been adequately focused on.

Purpose. The purpose of the article is to make discrete stochastic ARIMA models for forecasting the residual life of the pads of modernized BR devices for bogies of mainline and industrial rail cars.

To achieve this purpose, the following problems should be solved:

- performing an analysis of the design deficiencies of the elements of a typical BR of the bogie that cause the formation of tapered dual wear of the brake pads and identify the design advantages of the modernized BR;

- evaluating the influence of AR and MA components on the structural identification of ARIMA models;

- forecasting the remaining life of pads of modernized BR using the designed ARIMA models;

- evaluating the effect of the calculated residual life of the pads of the modernized BR on the entire guaranteed period between overhauls of freight cars of mainline and industrial railway transport.

Results. In modern operating conditions, the brake systems of bogies of freight cars that use a conventional brake rigging (BR) cannot ensure standard wear of the pads. This is due to both the design features of the BR and the failure of the M 1180.000 devices for uniform retraction of brake pads after a short period of operation [4].

In order to find rational design solutions to reduce the wear of brake pads caused by harmful phenomena resulting from the design features of the bogie with BR, a study was conducted on its structure to find that it has unnecessary connections. This prevents from both determining the kinematics and conducting an analysis, as well as finding inertial force factors that act on the BR from its elements [3]. Therefore, performing a force analysis of this complex mechanism requires imposing appropriate restrictions or considering its dynamics within the Lagrange equations of a system with flexible connections. In order to determine the forces in a link, its pliability within the interaction of elastic and inertial forces should be taken into account.

Since the BR of the bogie is symmetrical, it can be conditionally divided into two parts, which are referred to the first (right) and second (left) wheel pair to build a unified distribution scheme of power factors which effect the corresponding elements of the BR during braking (Fig. 1).

The analysis made it possible to identify a specific wear of brake pads, due to which local friction wear begin to appear
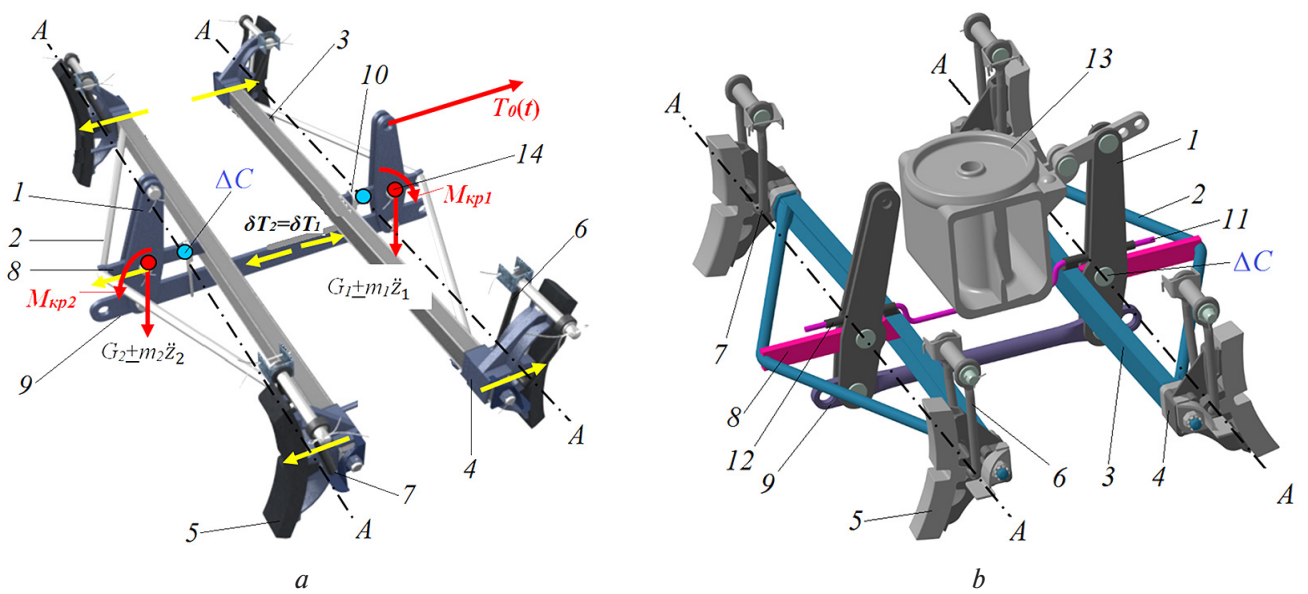

Fig. 1. General view of the BR model of a freight car [1, 3]:

$a$-typical design; $b$ - modernized design; $T_{0}(t)$ - external braking force; $\delta T_{2}=\delta T_{1}$ - internal "virtual" spacing forces; $L-$ distance to which the hole in the triangle spacer should be displaced 
only on their top not during braking, but when cars are moving in the traction and run-out modes. It is established that this adverse phenomenon occurs due to the low reliability of the device for uniform retraction of pads from the wheels and the imperfect design of the triangle. Therefore, because of the weight of the brake system components, the triangle is affected by static and dynamic forces $G_{1} \pm m_{1} \ddot{z}_{1}=G_{2} \pm m_{2} \ddot{z}_{2}$ (Fig. 2, $a$ ).

As a result of the action of this force on arm $L$, torque $M_{k p}$ occurs, and consequently, the triangle rotates around the lower hinges 7 of the pendulum suspension 6 (Fig. 1) until the top of both pads touches the rotating wheel pair of the car near the surface and is balanced by the reaction $\left(N_{1} / 2\right)$ tg, which begins to act on the point of contact of the brake pad with the rolling surfaces of the wheels of the car (Fig. 2).

All BR elements, the weight of which produces dynamic force $G_{1} \pm m_{1} \ddot{z}_{1}$ and torque $M_{k p}$, are connected by means of hinges with significant clearances, which are located in the non-sprung area of the bogie. Therefore, movement of the running gear of the freight car results in occurrence of forced oscillations of these BR elements, which consequently leads to alternating shock displacement in the clearances of the hinges under action of large static and dynamic components $G_{1} \pm m_{1} \ddot{z}_{1}=G_{2} \pm m_{2} \ddot{z}_{2}$.

It is known that in the devices that are designed to prevent abnormal wear of the pads and have different design features, countering action to the above forces occurs, so in operating conditions, such devices fail quickly and have a short service life resource [1].

To solve the problem of abnormal wear of freight car pads in the triangle brake system, torque $M_{k p}$ must be eliminated completely. For this purpose, some design changes in the elements of the triangle are necessary - the junction point of the spacer of a typical triangle with a vertical two-arm lever should be located on $A-A$ axis at $\Delta C$ point (Fig. 1, $a$ ), that is located on the same line and connects the hinges of the pendulum suspensions which are in the brake shoes with the pads of the cars. To solve this problem, distance $L$ from the existing hole (Fig. 2, b) red circle 4) to the new one (blue circle 4') should be minimized.

The method for designing a typical BR with the uniform retraction device M 1180.000 [4] was tested on the existing model (Fig. 1, $a$ ) without any structural changes in its elements. According to the results of kinetostatic calculations of BR elements, the reduction of harmful wear at the top of the brake pads was not recorded until the design of the triangle was modernized.

The purpose of the upgrade of the device (Fig. 1, b) was: first, the center of mass of the triangle had to be approximated as close as possible to the triangle beam 3 , so that the axis of the common center of gravity of triangle BR coincided with the lower joints 7 of the pendulum suspension 6 brake lining 4 and pad 5 . This can be achieved by displacing the connection hole of the node (hinge) 14 of the vertical two-arm lever 1 with the spacer 8 of the triangle 2 to the appropriate distance. For this purpose, the BR design (Fig. 1, a) should not include calipers for uniform wear with locks 10 , which do not perform their function. Second, instead of calipers with locks, a curved guide pin 11 should be installed in the cylindrical slides 12 to ensure a uniform distance between the brake pad 5 and the wheel on the released brakes in the traction and run-out modes of the train, regardless of the load on the spring beam of the car 13. Also, during maintenance of the brake system of bogies of freight cars, no cases of damage to the curved guide pin 11 were detected.

Thus, due to design changes in the BR, the problem of tapered dual wear of brake pads in the bogies of freight cars for the entire period of their operation between overhauls was solved, the number of wear intensity indicators in comparison with typical devices was reduced, and the BR began to function flawlessly.

As a rule, the approach to the analysis of sequences of observations, which are in chronological order includes resolution into the following components:

- seasonality;

- trend;

- residues (irregular components).

Decreased forecast accuracy may be associated with concealment of the trend and seasonality with residues. Therefore, the ability to forecast the components of the trend and seasonality determines the effectiveness of certain methods, as forecasting residues is inefficient [12, 13].

The combination of autoregression (AR) and moving average (MA) methods forms an ARIMA model that can simulate sequences over time.

Autoregressive model

$$
Y_{t}=c+\sum_{i=1}^{p} \varphi_{i} Y_{t-i}+\varepsilon_{t},
$$

where $c$ is constant value; $p$ is the order of the model; $Y_{t}$ is sequence values in time $t ; \varphi_{i}$ is coefficients of the model; $\varepsilon_{t}$ is residue in time $t$.

Moving average model

$$
Y_{t}=c+\sum_{i=1}^{q} \theta_{i} \varepsilon_{t-i}+\varepsilon_{t},
$$

where $q$ is the order of the model; $\theta_{i}$ is coefficients of the model.

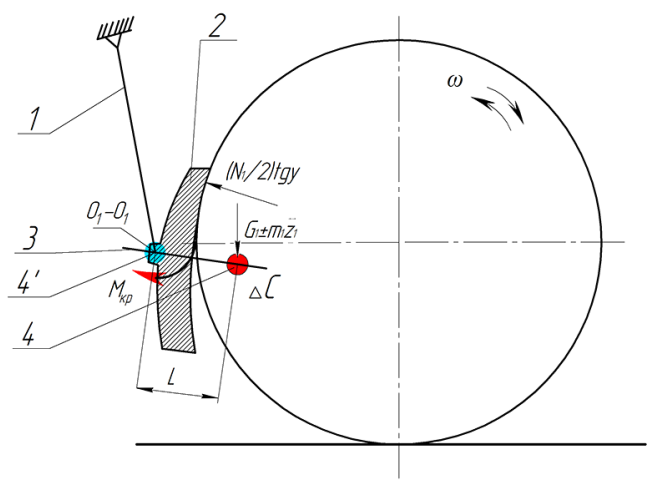

$a$

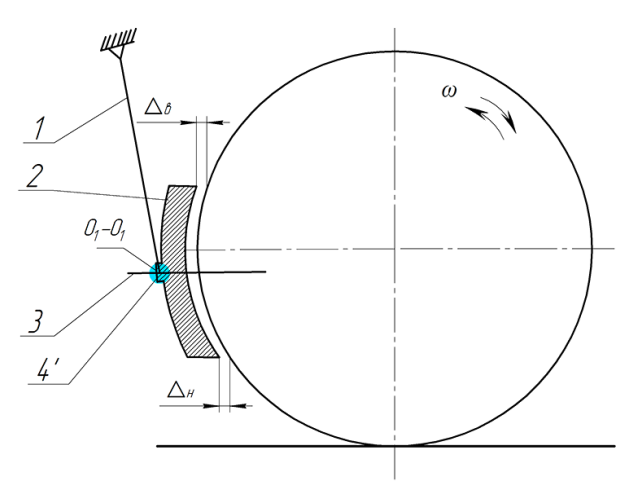

$b$

Fig. 2. Pressing the pad to the rolling surface during braking [1, 3]:

$a$ - actions of forces in which the dual wear of the pad is formed during the movement without braking; $b$ - even wear of the top and bottom of the pads; 1 -pendulum suspension; 2 - brake pad; 3 - triangle; 4 - hinge connection of the vertical lever with triangle; 4 '- hinge connection of the vertical lever with triangle that is conditionally displaced to the distance $L ; \Delta_{t} ; \Delta_{b}$-clearance at the top and bottom of the pad; $\gamma-$ angle between the direction of action of the reaction $N_{1}$ and the tangent to the point where the pad touches the wheel in the horizontal direction 
Determining the ARIMA model

$$
Y_{t}=c+\varepsilon_{t}+\sum_{i=1}^{p} \varphi_{i} Y_{t-i}+\sum_{i=1}^{q} \theta_{i} \varepsilon_{t-i}
$$

where $Y_{t}$ value is forecasted using the autoregressive model based on the linear approximation function of a limited number $p$ of previous $Y_{t}$. values. The autoregressive model is unnecessary when the residue increases, thus the moving average model can be useful, which describes the sequences as linear combinations of residue values, but the independent use of the moving average model has not become common. The ARIMA model is used to estimate future values of $Y_{t}$ based on the assumption of low impact of the residue $\varepsilon_{t}$. A complicated and non-stationary change of values in production processes cannot be taken into account by ARIMA models, which use linear time series to calculate the trend and forecast future values. Differentiation of different order is mostly used to bring the initial data to stationarity and at the next stage the ARIMA model is adjusted. For the actual forecast of values, a stationary time form is used, which is subsequently transformed to acquire the initial features.

The ARIMA model can solve the problem of reduction of sequences in time with signs of nonstationarity to stationarity

$$
\left(1-\sum_{i=1}^{p} \varphi_{i} L^{i}\right)(1-L)^{d} Y_{t}=\left(1+\sum_{i=1}^{q} \theta_{i} L^{i}\right) \varepsilon_{t}+c,
$$

where $L=Y_{t-1} / Y_{t}$ is lag; $d$ is the order of differentiation.

The form $(p, d, q)$ determines the order of the ARIMA model, where $p$ is the order of the autoregressive component, $d$ is the order of differentiation, $q$ is the order of the moving average component.

The procedure for formation of the ARIMA model requires the implementation of the following stages:

\section{Model definition:}

- choosing the order of differentiation d (integral part of the model) to acquire the features of stationarity, calculating the required number of consecutive differences $\left(Y_{t}=Y_{t}-Y_{t-1}\right)$. Here $d$ is almost always equal to one and this is sufficient to become stationary. The autocorrelation function (ACF) and the partial autocorrelation function (PACF) are used to confirm stationarity;

- determining the parameters of the ARMA model for the calculated stationary series $Y_{t}$ and then, tracking the nature of $\mathrm{ACF}$ and PACF, selecting the orders of $p$ and $q$.

2. Model evaluation.

Once $p$ and $q$ are selected at the previous stage, the coefficients $\varphi_{1}, \varphi_{2}, \ldots, \varphi_{p}$ and $\theta_{1}, \theta_{2}, \ldots, \theta_{p}$ are estimated using special numerical procedures, namely the method of least squares and the principle of maximum likelihood.

3. Determining the adequacy of the model.

According to the assumption of white noise of residues $\varepsilon_{t}$, which are used as information to assess the adequacy of the model, their non-correlation is checked. Further, information criteria are involved to adjust the selected class of ARIMA models during the structural identification of the optimal model.

According to the Akaiki Information Criterion (AIC), a model is selected that is designed to minimize statistical values

$$
A I C=\ln \hat{\sigma}^{2}+(2 / n) r,
$$

where $\hat{\sigma}^{2}$ is the dependence of the residual sum of squares on the number of observations; $n$ is the amount of residues; $r$ is the number of evaluated parameters of the model.

The Bayesian information criterion (BIC) is intended to choose a model that minimizes the expression

$$
B I C=\ln \hat{\sigma}^{2}+(\ln n / n) r .
$$

From the calculated AIC and BIS their lowest values are chosen; then the final choice of $p$ and $q$ for the corresponding subclass of models is made.

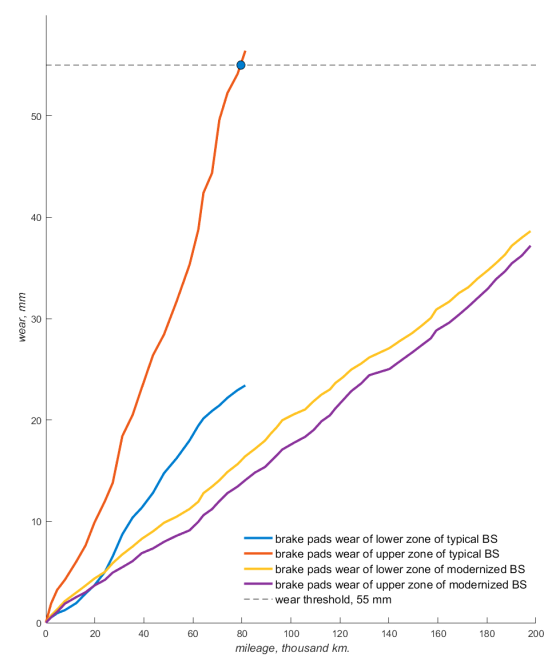

Fig. 3. Statistical results of wear of brake pads depending on the mileage of cars for typical and modernized brake systems

\section{Practical use of the forecasting model.}

The future value of the time sequence is forecasted by expression $Y_{t+s}=\varphi_{1} Y_{t+s-1}+\ldots+\varphi_{p+d} Y_{\mathrm{t}+s-p-d}$ after the optimal parameters of the model are calculated and the time sequence is restored by integrating $\mathrm{d}$ times.

The results of measuring the pad wear of typical and modernized retraction devices for BR of freight cars collected during operation on the main tracks of Ukrzaliznytsia JSC are shown in Fig. 3.

It was found that because of the design deficiencies of typical BR devices, when mileage of the car increases, the pads installed during depot repairs begin to wear intensively in the top, reaching the maximum standard wear, while in the bottom the wear is only minor and the residual body of the pad is significant. Unlike typical devices, in the modernized ones, the pads are worn out equally evenly on both parts due to structural changes in the BR elements.

The implementation of the first differentiation step $d=1$ was sufficient to acquire stationarity. Signs of the acquired stationarity of the time series are the rapid fall of the ACF coefficients within the established intervals. The parameters were selected depending on the behavior of the PACF, in particular, the order of the AR component was taken by the number of the lag that precedes falling within the boundaries of the set intervals. Also higher orders of AR - and MA-components and their combinations were taken separately to identify ARIMA models for both measurements of wear at the top and bottom of pad of the modernized BR device using minimum values of calculated AIC and BIC criteria (Tables 1,2).

Using the designed optimal ARIMA models (Table 3), the residual life of the pads of modernized BR devices was forecasted (Figs. 4, 5) with $95 \%$ confidence intervals [18]

$$
Y_{t+s \mid t} \pm 1.96 c \hat{\sigma}_{h},
$$

where $\hat{\sigma}_{h}$ is the root-mean-square deviation of the $s$-step of the forecast distribution.

So, due to the Box-Jenkins methodology, it is established that the maximum wear of $55 \mathrm{~mm}$ on the bottom of the pad of the modernized BR device will be achieved with the mileage of 276.6 thousand $\mathrm{km}$, and on the top of the pad - with the mileage of 273.3 thousand $\mathrm{km}$.

\section{Conclusions.}

1. It is established that in a typical BR due to a malfunction of the uniform retraction device (calipers with the lock), tapered dual wear of pads occur, so they have to be replaced with new ones during maintenance of cars ahead of schedule. However, studies on the use of modernized BR have shown an increase in the service life of brake pads by 1.67 times. The rea- 
Determining the parameters of the ARIMA model for the wear values of the bottom of the pad

\begin{tabular}{|l|c|c|c|c|c|c|c|c|c|}
\hline & \multicolumn{9}{|c|}{ Parameters of the ARIMA model } \\
\cline { 2 - 11 } & $(3,1,0)$ & $(4,1,0)$ & $(5,1,0)$ & $(6,1,0)$ & $(0,1,1)$ & $(2,1,2)$ & $(3,1,3)$ & $(4,1,4)$ & $(5,1,5)$ \\
\hline AIC & -79.97 & -85.23 & -86.89 & -86.33 & -78.53 & -88.74 & -92.45 & -98.75 & -95.77 \\
\hline BIC & -70.41 & -73.72 & -73.79 & -71.53 & -70.73 & -77.14 & -78.16 & -79.84 & -73.31 \\
\hline
\end{tabular}

Table 2

Determining the parameters of the ARIMA model for the wear values of the top of the pad

\begin{tabular}{|l|c|c|c|c|c|c|c|c|c|}
\hline & \multicolumn{9}{|c|}{ Parameters of the ARIMA model } \\
\cline { 2 - 11 } & $(3,1,0)$ & $(4,1,0)$ & $(5,1,0)$ & $(6,1,0)$ & $(0,1,1)$ & $(2,1,2)$ & $(3,1,3)$ & $(4,1,4)$ & $(5,1,5)$ \\
\hline AIC & -82.21 & -84.52 & -85.83 & -84.52 & -88.52 & -87.49 & -90.38 & -86.45 & -97 \\
\hline BIC & -72.65 & -72.71 & -72.73 & -69.72 & -80.72 & -75.9 & -75.1 & -67.53 & -76.71 \\
\hline
\end{tabular}

Table 3

Optimal ARIMA models for forecasting the remaining life of pads of modernized BR devices

\begin{tabular}{|l|c|}
\hline $\begin{array}{c}\text { Wear zone of the } \\
\text { pad }\end{array}$ & \multicolumn{1}{c|}{ Calculated coefficients of ARIMA models } \\
\hline Bottom & $\left(1-0.389 \cdot L+0.141 \cdot L^{2}+0.039 \cdot L^{3}-0.783 \cdot L^{4}\right)(1-L) Y_{t}=0.0075+\left(1-0.144 \cdot L+0.146 \cdot L^{2}+0.524 \cdot L^{3}-0.766 \cdot L^{4}\right) \varepsilon_{t}$ \\
\hline Top & $\begin{array}{l}\left(1+0.514 \cdot L+0.183 \cdot L^{2}-0.277 \cdot L^{3}-0.55 \cdot L^{4}-0.827 \cdot L^{5}\right)(1-L) Y_{t}=0.0062+\left(1+0.69 \cdot L+0.147 \cdot L^{2}-0.143 \cdot L^{3}-\right. \\
\left.-0.766 \cdot L^{4}-0.927 \cdot L^{5}\right) \varepsilon_{t}\end{array}$ \\
\hline
\end{tabular}

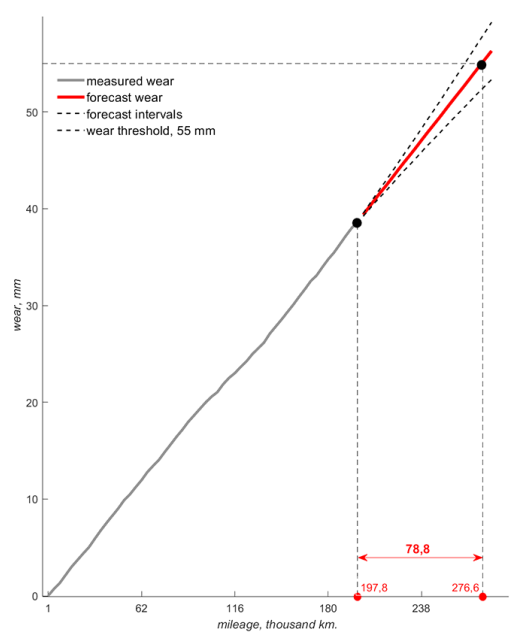

Fig. 4. Forecast of the remaining life of the bottom of the pad of the modernized BR device

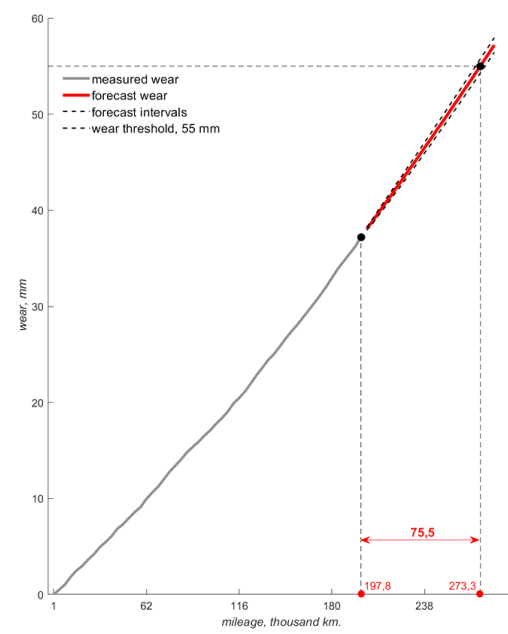

Fig. 5. Forecasting the remaining life of the top of the pad of the modernized BR device son is the change in position of the holes in the triangle strut and inclusion into the BR design of a curved guide pin to keep the pads when the brake is released at the same distance from the rotor surface of the wheels when the car is moving.

2. Because of the flexibility of the Box-Jenkins methodology for structural identification of ARIMA models, the most appropriate subclass of models among the ARIMA components can be chosen. A combination of AR and MA components demonstrated a better fit for forecasting the remaining life of pads, while individual AR and MA components implemented higher values of the AIC and BIC criteria.

3. Discrete stochastic ARIMA models can be successfully implemented provided discrete values are available that accumulate during the relevant experiments. Such disadvantages of ARIMA models as the higher complexity, the need to perform multiple iterative procedures and impossibility to implement an automatic process do not affect the successful determination of the remaining life, which is 78.8 thousand $\mathrm{km}$ for the top of the modernized BR device, and 75.5 thousand $\mathrm{km}$ for the bottom.

4. The residual life of the brake pads of the modernized BR devices is calculated to increase the average mileage of the car to 274.95 thousand $\mathrm{km}$, as well as to increase the period between overhauls in depot up to 3 years for freight cars of trunk and industrial railway transport. The results obtained in the study will be taken into account in the future in solving problems of abnormal wear of pads in the brake systems of bogies of freight cars of trunk and industrial railway transport.

\section{References.}

1. Ravlyuk, V. G., Afanasenko, I. M., \& Ravliuk, M. G. (2020). Investigation of the geometric parameters of the brake pads of freight cars under hazardous wear. Scienceand Transport Progress, 1(85), 99-118. https://doi.org/10.15802/stp2020/199515. 2. Department of Car Facilities (2019). Analysis of the state of train safety at the Ukrainian railways for 2019. Kyiv: Fast Motion. 3. Ravlyuk, V. G. (2019). Investigation of features of dual wear of pads in brake system of freight cars. Science and Transport Progress, 2(80), 11-126. https://doi.org/10.15802/stp2019/ 166114. 4. Operation Manual for Rolling Stock Brakes at the Ukrainian railways. $C T-C B-C L-0015$ (2004). Kyiv: Polygraphservice. 5. Vakkalagadda, M. R. K., Srivastava, D. K., Mishra, A., \& Racherla, V. (2015). Performance analyses of brake blocks 
used by Indian Railways. Wear, 328-329, 64-76. https://doi. org/10.1016/j.wear.2015.01.044.

6. Zhang, Y., \& Zhang, M. (2018). The application status of unit brakes on metro vehicles in China. IOSR Journal of Mechanical and Civil Engineering (IOSR-JMCE), 3(15), 17-23. https://doi.org/10.9790/1684-1503031723.

7. Vineesh, K.P., Vakkalagadda, M.R. K., Tripathi, A. K., Mishra, A., \& Racherla, V. (2016). Non-uniformity in braking in coaching and freight stock in Indian Railways and associated causes. Engineering Failure Analysis, 59, 493-508. https:// doi.org/10.1016/i.engfailanal.2015.11.023.

8. Matyjaszek, M., Fernandez, P. R., Krzemien, A., Wodarski, K., \& Valverfe, G. F. (2019). Forecasting coking coal prices by means of ARIMA models and neural networks, considering the transgenic time series theory. Resources Policy, 61, 283-292. https://doi.org/10.1016/j.resourpol.2019.02.017.

9. Prema, V., \& Rao, K. U. (2015). Time series decomposition model for accurate wind speed forecast. Renewables: Wind, Water, and Solar, 2(1), 18. https://doi.org/10.1186/s40807015-0018-9.

10. Zubenko, D., Kovalenko, A., \& Kuznetsov, O. (2015). Analysis of existing approaches to setting the intelligent management systems of transport undertakings. Eastern-European Journal of Enterprise Technologies, 9(78), 17-22. https://doi. org/10.15587/1729-4061.2015.56693.

11. Box, G. E. P., Jenkins, G. M., Reinsel, G. C., \& Ljung, G. M. (2016). Time series analysis. Forecasting and control. $5^{\text {th }}$ edition. New Jersey: Wiley \& Sons, 712.

12. Martinez-Alvarez, F., Troncoso, A., Asencio-Cortes, G., \& Riquelme, J.C. (2015). A survey on data mining techniques applied to electricity-related time series forecasting. Energies, 8(11), 13162-13193. https://doi.org/10.3390/ en81112361.

13. Mykhalkiv, S., \& Bulba, V. (2019). The forecasting of the technical state of the traction gearboxes of electric trains with discrete stochastic models. Collected Scientific Works of Ukrainian State University of Railway Transport, 188, 23-35. https:// doi.org/10.18664/1994-7852.188.2019.206182.

14. Meer van der, D.W., Shepero, M., Svensson, A., Widen, J., \& Munkhammar, J. (2018). Probabilistic forecasting of electricity consumption, photovoltaic power generation and net demand of an individual building using Gaussian Procesesses. Applied Energy, 213, 195-207. https://doi.org/10.1016/j. apenergy.2017.12.104.

15. Pavlyukov, A. E., Cherepov, O. V., \& Shalupin, I. A. (2017). Freight wagon brake pads: analysis of damage and factors affecting the creation of braking force. Bulletin of the Ural State University of Communication, 4(36), 4-11.

16. Sinitsyn, V. V., \& Kobishchanov, V. V. (2020). Braking system for bogie successive braking of freight cars. Bulletin of the Bryansk State Technical University, 3(88), 21-28. https://doi. org/10.30987/1999-8775-2020-3-21-28.

17. Tuluzin, S. V., \& Gorskij, D. V. (2015). Performance assessment of the brake rigging of the bogie of the freight car at various stages of wear of pads and wheels. Bulletin VNIIZHT, 2, 38-44.

18. Hyndman, R. J., \& Athanasopoulos, G. (2018). Forecasting: Principles and Practice ( $2^{\text {nd }}$ ed.). OTexts.

\section{Прогнозування зносу колодок модернізованих пристроїв гальмових систем візків вантажних вагонів ARIMA моделями}

\author{
В. Г. Равлюк ${ }^{1}$, С. В. Михалків ${ }^{1}$, А. В. Рибін ${ }^{1}$, \\ Я. В. Дерев'янчук ${ }^{1}$, О.А. Плахтій ${ }^{2}$
}

1 - Український державний університет залізничного транспорту, м. Харків, Україна, e-mail: svm_m@ukr.net 2 - Товариство 3 обмеженою відповідальністю «ВО ОВЕН», м. Харків, Україна
Мета. Полягає в побудові дискретних стохастичних ARIMA моделей для прогнозування залишкового ресурсу колодок модернізованих пристроїв гальмово-важільної передачі (ГВП) візків вантажних вагонів промислового транспорту.

Методика. Облік статистичних даних зі зносу колодок типових і модернізованих пристроїв ГВП на відповідних обстеженнях. Аналітичні розрахунки ГВП, за результатами яких запропоновані зміни у вузлі з'єднання вертикального важеля з розпіркою. Інформаційний критерій Акайкі й Байєса для вибору оптимальної інтегрованої моделі авторегресії та ковзного середнього у межах методології Бокса-Дженкінса для прогнозування залишкового ресурсу колодок.

Результати. Здійснена ідентифікація, оцінювання, перевірка адекватності ARIMA моделі за інформаційними критеріями Акайкі й Байєса. Установлено, що ненормативний рівень зносу верхніх частин колодок типових пристроїв ГВП унаслідок низки конструктивних і експлуатаційних причин досягається за пробігу, що майже у 3,5 рази коротший за прогнозований пробіг, за якого відбувається ненормативний знос верхньої частини колодок модернізованих пристроїв ГВП. Прогнозований залишковий ресурс верхньої частини колодки модернізованого ГВП на 3,3 тис. км коротший за аналогічний для нижньої частини цієї ж колодки.

Наукова новизна. Уперше здійснено прогнозування залишкового ресурсу колодок модернізованих пристроїв ГВП вантажних вагонів промислового транспорту дискретними стохастичними АРIMА моделями, що потребують лише наявності дискретних величин, які реєструються протягом відповідних експериментальних замірів.

Практична значимість. Результати проведених досліджень апробовані на дослідному рухомому складі з модернізованими пристроями у гальмових системах візків. Їх можна використовувати при проектуванні, модернізації та експлуатації гальмових систем як експлуатаційного парку, так і нового покоління візків вантажних вагонів.

Ключові слова: ARIMA модель, вантажний вагон, гальмова важільна передача, гальмова колодка, знос, прогнозування

\section{Прогнозирование износа колодок модернизированных устройств тормозных систем тележек грузовых вагонов ARIMA моделями}

\section{В. Г. Равлюк ${ }^{1}$, С. В. Михалкив ${ }^{1}$, А. В. Рыбин ${ }^{1}$, Я. В. Деревянчук ${ }^{1}$, А. А. Плахтий ${ }^{2}$}

$1-$ Украинский государственный университет железнодорожного транспорта, г. Харьков, Украина, e-mail: svm_m@ukr.net

$2-\overline{\mathrm{OOO}}$ «О ОВЕН», г. Харьков, Украина

Цель. Заключается в построении дискретных стохастических ARIMA моделей для прогнозирования остаточного ресурса колодок модернизированных устройств тормозной рычажной передачи (ТРП) тележек грузовых вагонов промышленного транспорта.

Методика. Учет статистических данных по износу колодок типовых и модернизированных устройств ТРП на соответствующих осмотрах. Аналитические расчеты ТРП, по результатам которых предложены изменения в узле соединения вертикального рычага с распоркой. Информационный критерий Акайки и Байеса для выбора оптимальной интегрированной модели авторегрессии и скользящего среднего в рамках методологии БоксаДженкинса для прогнозирования остаточного ресурса колодок. 
Результаты. Осуществлена идентификация, проверка адекватности ARIMA модели по информационным критериям Акайки и Байеса. Установлено, что ненормативный уровень износа верхних частей колодок типовых устройств ТРП вследствие низких конструктивных и эксплуатационных причин достигается при пробеге, который почти в 3,5 раза короче прогнозированного пробега, при котором происходит ненормативный износ верхней части колодок модернизированных устройств ТРП. Прогнозируемый остаточный ресурс верхней части колодки модернизированного ТРП на 3,3 тыс. км короче аналогичного значения для нижней части этой колодки.

Научная новизна. Впервые осуществлено прогнозирование остаточного ресурса колодок модернизированных устройств ТРП грузовых вагонов промышленного транспорта дискретными стохастическими ARIMA мо- делями, которые требуют наличия дискретных величин, регистрируемых в течение соответствующих экспериментальных измерений.

Практическая значимость. Результаты проведенных исследований апробированы на опытном подвижном составе с модернизированными устройствами в тормозных системах тележек. Их можно использовать при проектировании, модернизации и эксплуатации тормозных систем как эксплуатационного парка, так и тележек грузовых вагонов нового поколения.

Ключевые слова: ARIMA модель, грузовой вагон, износ, прогнозирование, тормозная колодка, тормозная рычажная передача

Recommended for publication by A.A.Plugin, Doctor of Technical Sciences. The manuscript was submitted 29.05.20. 